\title{
Confusing cases: Forrester, Stoller, Agnes, woman
}

\author{
Julie Walsh \\ University of Essex, UK
}

\begin{abstract}
This article pursues the hypothesis that there is a structural affinity between the case study as a genre of writing and the question of gendered subjectivity. With John Forrester's chapter 'Inventing Gender Identity: The Case of Agnes' as my starting point, I ask how the case of Agnes continues to inform our understanding of different disciplinary approaches (sociological and psychoanalytic) to theorising gender. I establish a conversation between distinct, psychoanalytically informed feminisms (Simone De Beauvoir, Juliet Mitchell, Judith Butler and Denise Riley) to move from the mid- $20^{\text {th }}$ century, to contemporary cultural debate.
\end{abstract}

\section{Keywords}

case thinking/writing, feminisms, John Forrester, gender, psychoanalysis

\section{Corresponding author:}

Julie Walsh, University of Essex, Centre for Psychoanalytic Studies, Department of Psychosocial and Psychoanalytic Studies, Wivenhoe Park, Colchester, CO4 3SQ, UK.

Email: julie.walsh@essex.ac.uk 
In the final and incomplete chapter of his Thinking in Cases, 'Inventing Gender Identity: The Case of Agnes', John Forrester recounts the treatment of 'Agnes', whose womanhood was famously investigated throughout her adult life by 'two practitioners from different fields'; Robert J. Stoller, the psychoanalyst and UCLA Professor of Psychiatry renowned for his work on 'gender identity', and his close colleague Harold Garfinkel whose work on the concept of 'passing' was key to his development of an ethnomethodological approach within sociology (2017: 130). Forrester explains that as 'one of the principal innovators of the contemporary concept of gender', Robert Stoller advanced on John Money's 1955 introduction of the term to the psychological lexicon by coining the compound phrase 'gender identity', intended in part to further distinguish 'gender' from 'sex' (ibid.: 129). The degree to which this distinction then took hold within both scientific and everyday language practices is well known: the words of the sexologist Harry Benjamin, 'sex is below the belt, gender is above the belt' communicate effectively the established positions of late- $20^{\text {th }}$-century discourse (by no means redundant today, as we shall see) where 'gender' speaks to a psychosocial construct, whereas 'sex' remains tied to a biological or anatomical 'fact' (ibid.: 131). Offering a critical genealogy of this discursive split is key to Forrester's project: he explores various 'historical conjunctions' through which the gender story can be narrated; from how the concept gained purchase within the psy. disciplines from the 1960s on; to how developments in modern medical technologies, including surgical procedures and hormone therapies, intersected with an ascendant political culture that mobilised identity as a key term; and on to the more speculative line of inquiry asking whether the dictates of choice (consumer choice, rational choice) may be rendering obsolete the conceptual apparatus of sex and gender that Stoller and others were so instrumental in instituting (ibid.: 136). Indeed, it is the future of the distinction between sex and gender that Forrester leaves us pondering, a future in which the historical case of Agnes still plays a part. 
In 1958, at 19 years of age, 'Agnes' volunteered her participation in a study on intersexuality at UCLA hoping to be referred, with financial assistance, for what would come to be known as gender reassignment surgery. In their co-authored paper, Stoller, Garfinkel and Alexander C. Rosen introduce Agnes's biography as follows:

She was born a boy, with normal-appearing male genitalia. A birth certificate was issued for a male and she was appropriately named. [...] Having been designated a boy by the ascriptions of medical science, the law, and all the individuals of her society, she had no choice but to comply (at least on the surface), though she felt an almost overwhelming pull in the direction of femininity. [...] With puberty began the development of secondary sex characteristics of a feminine nature. (1960: 379)

Agnes's presentation to the research team warranted the feminine pronoun: 'it was not possible for any of the observers, including those who knew of her anatomic state, to identify her as anything but a young woman' (ibid.: 380). As a woman, in other words, she 'passed', but nonetheless remained a medical and psychological 'mystery' (Hughes, 1999: 94). In 1959, Agnes was granted the surgery that befitted her with the genitalia of her choice. Some years later, returning to UCLA for psychotherapeutic treatment, Agnes disclosed to Stoller that from the age of 12 she had been surreptitiously taking her mother's oestrogen replacement hormones, thus explaining away the 'mystery' of her pubescent 'feminization'. On learning of the exogenous causes behind Agnes remarkable feminisation, Stoller wrote that his "chagrin was matched by [his] amusement that she could have pulled off this coup with such skill' (Stoller, 1984[1968]: 136). But if her 'skill' was to be admired (after all, she had blindsided the researchers), didn't it also compromise the science? Importantly, the projects of the 
psychoanalyst (Stoller) and the sociologist (Garfinkel) were differently affected by this new information.

For Stoller, Agnes's 'confession' prompted her re-categorisation from that of an intersex case to that of a transsexual (Forrester, 2017: 133). It also enabled him to narrate a new aetiology. Only once Agnes had 'confessed', could she 'deal openly' with him about childhood matters and permit him to talk with her mother (Stoller, 1984[1968]: 136). Here Stoller developed his speculations around 'excessive mother-infant symbiosis' and its links to transsexuality. ${ }^{1}$ The implications of Agnes's revelation for Garfinkel's project are rather different. As sociologist Kristen Schilt notes, 'while the facts of Agnes's life shifted [...] the analytic importance of her case study to ethnomethodology did not', for the case confirmed that 'doctors, just as lay persons, determined gender on the basis of appearance and behaviour' (2016: 292). In fact Garfinkel's account of the case, 'Passing and the managed achievement of sex status in an "intersexed" person: part 1', was already in press when he learned from Stoller the truth about Agnes. Yet, even had the news of the deception arrived in time, it is difficult to imagine how it might have challenged Garfinkel's culturalist model. He had always stressed that it was Agnes's 'conviction [...] that she was naturally, originally, really, after all female' that put the case beyond doubt: 'no mockery or masquerading accompanied [her] claim that [he was] able to observe' (??: 164-5). Ambiguity and doubt are the enemy of conviction, therefore to 'pass' as a woman, in the sense that was necessary for Agnes - especially given the legal and medical implications of her case - called for a consummate and consistent performance of self. ${ }^{2}$ To use the phrase that took hold among the UCLA team, Agnes presented as '120\% female' (??: 129).

Adding here to the underlying confusion of biological, cultural, and aetiological designations of Agnes's sex/gender status, is its temporalization. It is not only a question of how we define Agnes, but when we define her. Do we designate her at birth, at first glance, 
before or after surgery, before or after her confession, before or after talking with her mother? And what of the question of historical variation? As Forrester argues, the circulation of hormone therapies as an 'everyday gender sustaining behaviour' in the 1960s is a crucial historical development that 'subverts the possibility of providing any clear-cut definition of gender as "natural"' (??: 136). Constitutive of the nature of Agnes's femaleness then, was the unnatural supplement of her mother's hormones that remained concealed from view. The question we might ask of Stoller and Garfinkel is whether their measurement of Agnes's femaleness (120\%) went up or down as a consequence of her confession; does Agnes become more or less woman, in other words, once we know her feminization was achieved through exogenous means? If, as has been a mainstay of psychoanalytic thought since Freud, feminine psychology coincides with the principles and practices of the masquerade (see Heath, 1986; Lacan, 1982; Riviere, 1929; Rose, 1982), Agnes's masterful dissemblance - her successful duping of her male interaction partners over a sustained period of time - arguably furthers her claim to be a 'real woman'.

To be sure, truncating a single case - and, at that, one as multiple as Agnes's - to this synopsis, betrays the very logic of the case study as a form of writing, which, I will be arguing, is designed to give space to the many and often contrary lines of study that emerge from within the patient-analyst experience. For the purposes of initiating my discussion, however, I want to excuse such a reductive rendering and extract one rudimentary observation: the case of Agnes, which functions as a kind of 'test case' in the new studies of gender identity, confounds the expectations of classificatory and categorical thinking. Agnes's active confusion of the classificatory system within which she was placed demonstrates the failure of categorical language to capture the particularity of her experience as a sexed and gendered subject. Moreover, this failure is necessarily transferred to the act of writing the case-study itself. Could it be said that Agnes and the case-study writer share a common dilemma, namely to find a form 
of expression that both attends to the particularity of subjective experience and answers to a general interpretative frame of reference? When Stoller et al. first introduced Agnes in 1960, they provided the following qualification: 'the patient has contrived their biography to state a particular point of view - that she is truly a girl. Thus the following outline need not be accepted at face value' (??: 379). Evoking, through the language of contrivance, the patient as an unreliable narrator, the clinical writing extends the epistemological ambiguity of its subject through the communication that what you are about to read need not be taken at face value. Leaving aside for now what it might mean to be a wholly reliable narrator of one's gender identity, I want to develop in this article the suggestion that there may be a structural affinity between the case study as a genre of writing and the question of gendered subjectivity. Putting it somewhat differently, I want to ask whether we might we allow that the general case of 'woman' continues to have a special relevance to the peculiar practice of the case study as a mode of writing and thinking?

\section{Confusion: Categories, classes, cases}

Categories are deployed to speak about identity: to categorize is to endeavor to make intelligible a particular object of knowledge, to set it apart from that which it may be close to but, ultimately, isn't the same as. To categorize is to demarcate the identifying characteristics of a thing, to say something like - 'I know you, now that I can name you'. This means that to invest in categories is to be constantly vulnerable to making a category error, or at the very least falling into a category confusion.

Different disciplines have different thinking styles that accord with their objects of study; they also have different nomenclatures, comprised of specialist, sometimes sacred terms that don't necessarily make for easy interdisciplinary conversations. For example, the categorizing impulse of the sociologist, (at least historically conceived), derives from her 
commitment to studying social reality, where categories matter greatly - the birth certificate, the school uniform, the navigation of public bathrooms, the bureaucratic and institutional documents that record and give shape to our private and intimate lives. To say that categories organize our subjective experience of social reality is to posit them as structuring forces with histories worthy of scrutiny. How has it come to pass, for example, that in the 1960s my mother was prohibited by the bank manager from opening an account in her own name on the grounds of her marital status; whereas today, in 2018, and depending on how I choose to bank, my account can bear the mark of Mx. (a title indicating a non-binary identification), rather than Miss, Ms, or Mrs? Because the story of how Mx. has come to pass is a story of complex historical and social transition, its fullest articulation requires a specifically transdisciplinary analysis, one, I would argue, that benefits considerably from an engagement with psychoanalysis and the thinking styles found therein. Unlike the sociologist, the psychoanalyst's strict concern is with 'psychical reality', that register of experience (pointing to a distinct epistemology) so-called by Freud to advert to the ways in which the operating system of the unconscious differs radically from the familiar functioning of everyday thought.

Securely hypothesized though never directly encountered, the unconscious is animated by a peculiar set of principles, the most formative of which concerns its consubstantiality with sexuality (Lacan, 1998[1978]: 146). To say, in the Freudian model, that the dimensions of the unconscious are consubstantial with sexuality, is to say, as Joan Copjec does, that 'sex is the stumbling block of sense', that it 'serves no other function than to limit reason, to remove the subject from the realm of possible experience or pure understanding' (Copjec, 1994: 18, 21). Put simply, in tying together the unconscious and the question of sex - the knot of sex, we might say - psychoanalysis axiomatically undermines the idea that we can be wholly secure, or firmly fixed in our knowledge claims about our human sexuality. Accordingly, many practitioners or theorists of psychoanalysis are going to be advocates for a degree of confusion 
- not the torturous, paralyzing kind that prohibits movement of body or mind, but the kind of confusion that signals a tolerance of ambiguity, and a sensitivity to the faltering irresolutions behind identity statements. A mode of confusion, in other words, that hints at a capacity to bare the inevitable not-knowing that accompanies the knot of sex: how we do it, how it undoes us.

The question of whether such a psychoanalytic disposition may prove itself a productive ally for those working to trouble the categories of sex and gender has been answered affirmatively in much queer discourse. Perhaps it goes without saying that the prominence of queer studies in recent decades with its commitment to querying categories through tactics of 'subversive confusion' 3 for example, shares in what Maggie Nelson playfully calls her 'identity phobia' (2015: 139). ${ }^{4}$ And yet, though care should be taken to distinguish cause from correlation, queer discourse has also marked a resurgence of identity politics such that it can sometimes seem as if it is in the business of proliferating categories (serially extending acronyms by an extra initial) rather than doing away with them. Although queer theory does not in itself sanction sectional politics, it has profoundly informed recent political debate, the most prominent example being a particular strand of the dialogue (though failure to dialogue may be a better description) between queer-trans logics and entrenched, so-called feminist positions where, despite the apparent certainty of the knowledge claims of those involved, the site of confusion is womanhood itself.

As far as the individual is concerned, there are innumerable reasons why 'I know you, now that I can name you' will inspire horror for some, relief for others. As per Eve KosofskySedgwick's satisfying first axiom in her Epistemology of the Closet, 'people are different from each other' (1990: 22). The psychoanalytic case study attends to such difference. The psychoanalyst follows the ethnographer in her commitment to thick description by making 'exceedingly extended acquaintances with extremely small matters', to use Clifford Geertz's enticing phrase (Geertz, 1973: 21). The smaller the better, we might venture, is a principle of 
psychoanalytic practice, and, therefore, also of psychoanalytic writing. But how does such a principle abet psychoanalysis's more systemic epistemological ambitions? And more specifically on the question of sex/gender, how can the kind of thinking in cases that characterises psychoanalysis converse with the knowledge claims made by the sociologist, the sexologist, or the demographer?

As per the framework of John Forrester's project, the pressing methodological and epistemological challenge raised by thinking in cases concerns the possibility of moving beyond the textured singularity of the case study, to a level of reliable generality. This concern plays itself out in the writing task, where the case-study writer endeavours to do justice to their chosen case. But if case-study writing entails communicating something of the intimacy of the analytic encounter, something of its peculiar suspension of social conventions, as well communicating something of the fluctuating emotional intensity of the spoken and unspoken dialogue between the two subjects involved, then, irrespective of the particular clinical phenomenon it broaches, the case-study is a medium that will necessarily fall short of representing the case-subject in its entirety. Of course, in one sense, this is only the logical symptom of the theory of language that psychoanalysis espouses, meaning that we should well expect the case studies we read to perform some of the same frustrations the analyst has borne witness to on the couch (i.e. frustrations of the human subject's failure to know what they say). But the more pertinent sense in which this failure of self-knowledge holds, concerns the fundamental ambiguity regarding just who or what is being framed as the subject of the case (for instance, whether Freud's 'Dora' tells us more about Sigmund Freud than Ida Bauer is, ultimately, a judgement call for the reader to make). ${ }^{5}$ In this regard, Forrester's claim that the case study functions as an attempt to 'convey the unique psychoanalytic experience of both patient and analyst', though uncomplicated at first glance, has important implications for the debates regarding the research value of the case study method (Forrester, 2017: 65). When the 
methodological pros and cons of the psychoanalytic case-study are rehearsed, as they have been since Freud's time of writing, invariably a question arises along the following lines: are the attractions of the case-study method (such as the richness of the data it yields, and its dramatization of clinical phenomena) sufficient compensation for its limitations (e.g. its failure to arrive, through reproducibility, at objective knowledge) $?^{6}$ Irrespective of how one answers the question, we wouldn't want to overlook how the so-called singularity of the case-study paradoxically comprises the both/and of the patient/analyst. As a mode of writing, then, the case-study form, is, from the outset, multiple. ${ }^{7}$ It is a commonplace in psychoanalysis that intimate scenes become overcrowded very quickly: Freud reported that he was 'accustoming [himself] to regarding every sexual act as a process in which four individuals are involved'; to which we might add 'at least', once we consider how the play of identifications in the field of transference and countertransference encourages the numbers to proliferate (Freud in Masson: 364). This is especially pertinent to the requirement that, as a written form, the case study be read, meaning that the ambition to communicate "the unique psychoanalytic experience of both patient and analyst' only realises itself through the additional figure of the reader, a figure who necessarily brings along her own hermeneutic identifications to the exchange.

So far, so general. Having sketched some observations regarding the case study as a genre of writing, we might now ask what have they to do with the particularities of gender, or with the question of 'woman' as it continues to be posed today? That the woman question still has the capacity to confuse those who ask it has been manifest in recent cultural debates surrounding what many have termed the transgender moment. I want to turn to a media vignette to explore this, namely a 2016 interview from an episode of the BBC programme Newsnight entitled 'Is Transgender the New Civil Rights Frontier?'. Here we will observe the contested ground between cases, classes and categories, and notice also the discursive pressure on the interview to make general the particularity of the experience of being a woman. We will then 
go on to see how the sites of confusion that trip-up our contemporary cultural commentators have been well rehearsed in the history of feminist thought.

\section{A Freudian slip?}

The context for the Newsnight piece is the reporting of the transgender equality inquiry chaired by the conservative MP Maria Miller on behalf of the UK government's Women and Equalities Committee in 2016. The most significant recommendation of the inquiry concerns the processes through which a legal change to one's gender / sex status would be recognized, replacing the requirement for an official diagnosis of gender dysphoria (and evidence of having lived in one's 'acquired' gender for a minimum of two years), with the logic of self-declaration.

As per the conventions of television interviews, a debate structure is established with the interviewer, Emily Maitlis, positioned between the feminist writer and journalist Sarah Ditum on the one side, and the trans activist, writer and musician, C.N. Lester, on the other. The effect being that the rhetorical 'either/or' (or, pick your side) formally reinforces the binary logic that (on one side at least) is deeply contested. The dialogue that ensues navigates several of the dominant concerns of the transgender debates as they've been configured in mainstream discourse, as well performing some of the principal anxieties that have animated them. In short, Sarah Ditum maintains that because 'sex classes' ('men and women'), 'broadly map onto physical sex' ('male and female'), a public conversation focusing exclusively on trans rights (which she deems 'a fascinating, but small part of the argument') risks overlooking the structural violence practiced by men against women; CN Lester argues, with an emphasis on the doing as opposed than the being of sex and gender, that the full recognition of trans rights is not a minoritarian concern but rather has wide-reaching consequences for 'our general way of being in society with each other'. In her role as middle man, Emily Maitlis faces two ways. She puts it to her guest who identifies as transgender that they 'are in danger of blurring all the 
lines, all the social constructs', making it impossible to know where the definitions lie, and ushering-in all manner of difficulties for legislation and data monitoring; then, to her other guest, she identifies an alternative danger, namely that history will show that 'the revolution was happening and [she was] on the wrong side. [She] didn't realize that this was a civil rights movement in the way that race was, or in the way that the gay movement was'. With the lines thus drawn, the psychodynamics of the interview prove fascinating, and it is not incidental that the detail of the inquiry's proposals are hardly discussed at all. ${ }^{8}$ Here is an excerpt:

EM: CN, how would you describe yourself if faced with a form or application, what do you write?

CNL: For someone like me who is transgender and does not consider themselves either male or female and goes through the world being treated sometimes as a man and sometimes as a woman, it gets very confusing when I'm asked to accurately describe who I am. I want to tell the truth, I want to be honest about my experiences, and if a form simply has male or female there's no way I can do that.

EM: Why do you get [...] why is it confusing, why do you get sometimes described as a man and sometimes as a woman? [my emphasis]

CNL: I think it's because we have different ways of seeing sex and the gender. If we look at the history of how we do gender -how we do gender and sex- we've always had creative ways of doing gender. We have people who transition from one sex to another, we have people who live in a space which is between genders, we have people who reject ideas of gender at all.

EM: [interrupting] But, you were born a woman....

CNL: No, I was born baby, I think there's quite a big distinction there! And in fact because of the patriarchal system in Hong Kong I do not even have female on my birth 
certificate, I have 'girl' because it was very old-fashioned.

SD: Can I jump in there: that's exactly the distinction we need to be talking about. Girl is gender which is social role, but male and female are physical sex, and they are different things. The nature of transition and the reason transition is traumatic is because physical sex is a fact of biological reality which trans people have to negotiate.

CNL: I'm going to jump in there again, as this is one of my academic specialities. The idea of sex as we now know it emerged in the 19th century in French Sexology. We can't talk about sex without talking about the gendering of bodies, the ways that bodies have been classified in different ways. If we come back to the issue at hand, which is about the current legislation...

EM: Wait a second, what does that mean then? You're saying that the idea of male and female does not exist in your mind?

CNL: No, I'm saying that the idea of male and female is far more complicated than what we were taught at GCSE biology. None of us are biologists. It would be interesting to talk about what is actually going on as opposed to these common misunderstandings that we have.

SD: It is immensely complicated in some ways and in other ways it's enormously simple in that in day-to-day life there are men and women who are, broadly, male and female, so sex classes broadly map onto physical sex. The ways in which trans people are caught and pressured between those classes are really important and something I really hope Maria Miller's report will begin to deal with constructively. But, in everyday life, the oppression of women by men follows the line of sex, and it is about the exploitation of women as a sex class. 
Ultimately, this is an exchange in which language is on trial: throughout the conversation there is a constant tension between the different registers of discourse being rehearsed. The commitment to speaking 'broadly' (Ditum), is a commitment to speaking to the level of classes, or populations, where statements of general representability can be made. The commonly held version of the gender/sex distinction $($ girl $=$ gender $=$ social role; female $=$ physical $\operatorname{sex}[=$ natural/biological fact]) is offered confidently by Ditum, but then rebuffed with comparable confidence by Lester in the name of a superior knowledge, an academic specialism. ${ }^{9}$ To query the self-evident status of a 'sex class' is to point to the complex discursive practices that have produced the body - its legibility and legitimacy - in sexed and gendered terms. But language here tends towards proliferation; wary of the reductionisms and false equivalences housed under an equals sign ('='), it works to keep the referent-object open and mobile, refusing to be pinned down for the sake of a categorical definition. There is, then, a communicative impasse staged in this conversation, a confusion of tongues we might say.

There is also a rather alarming slip of the tongue: Following Lester's response to the opening question about self-description, where they explain the confusion felt when established lexical conventions do not permit them to tell the truth of their experiences, Maitlis persists with a thrice 'why'. Her line of questioning is intended to elicit greater clarity, perhaps greater singularity from her interviewee: 'Why do you get [...] why is it confusing, why do you get sometimes described as a man and sometimes as a woman?'. Lester's response is shortly interrupted by, not an interviewer's question as such, but a designating statement: 'you were born a woman...', prefaced with a 'but' - 'but, you were born a woman...' - and followed by the smallest of pauses (amplified by the camera though absent on the page), which leaves us to wonder whether Maitlis is catching on to her own, rather significant, category confusion. The speed and assuredness with which Lester then replies - 'No, I was born a baby!' - indicates that this isn't a declaration that merits any ambiguity (though the psychoanalyst D.W. 
Winnicott might have something different to say). ${ }^{10}$ If Maitlis's designation (possibly accusation?) 'but you were born a woman' is a slip that reveals the precarious status of what we know about sex, it is also one with a formidable citational charge.

As a formulation on the theme of becoming, Simone de Beauvoir's 1949 thesis that 'one is not born, but rather becomes, a woman' has acquired a self-evident status - all the more reason, perhaps, to consider in greater detail the language surrounding the soundbite.

One is not born, but rather becomes, a woman. No biological, psychological, or economic fate determines the figure that the human female presents in society; it is civilization as a whole that produces this creature, intermediate between male and eunuch, which is described as feminine. (1997: 295)

With these intriguing words begins the first chapter of Book Two of The Second Sex. ${ }^{11}$ Woman, as she has come to pass, is a figuration, a presentation that could have been otherwise: the human female was never predestined to become this intermediate creature that, in 1949, answers to the name 'woman'. Cursorily at least, de Beauvoir's famous dictum resonates well with Freud's late formulation from his 1933 Lecture on 'Femininity': 'psychoanalysis does not try to describe what a woman is - that would be a task it could scarcely perform - but sets about inquiring how she comes into being' (ibid.: 116). Indeed, de Beauvoir credits psychoanalysis, and its advance on 'psychophysiology', for insisting that 'no factor becomes involved in the psychic life without having taken on human significance; it is not the bodyobject described by biologists that actually exists, but the body as lived in by the subject' (ibid.: 69). It is, then, as a human science, where living in a body means living in a body in a human culture, that psychoanalysis offers itself to a feminist project. However, where certain feminisms embraced psychoanalysis as 'the best guarantee against a lapse back into the 
essentialist doctrine of original femininity', de Beauvoir kept more of a distance (Appignanesi and Forrester, 2005[1992]: 461). This is because she regards the psychoanalytic point of view as offering woman only 'two modes of alienation':

Evidently to play at being a man will be for her [woman] a source of frustration; but to play at being a woman is also a delusion: to be a woman would mean to be the object, the Other - and the Other nevertheless remains subject in the midst of her resignation. (??: 82-3)

De Beauvoir can find little scope for self-definition, or becoming otherwise in the psychoanalytic model.

When, in her 1974 text Psychoanalysis and Feminism, Juliet Mitchell engages de Beauvoir's critique she highlights the following passage:

[...] I shall pose the problem of feminine destiny quite otherwise [than it is proposed by psychoanalysis]: I shall place woman in a world of values and give her behavior a dimension of liberty. I believe that she has the power to choose between the assertion of her transcendence and her alienation as object; she is not the plaything of contradictory drives; she devises solutions of diverse values in the ethical scale. (Mitchell, 2000[1974] [citing de Beauvoir]: 309)

Mitchell allows that given the "all-prevailing "choice"" in which de Beauvoir invests, "the Freudian stress on the significance of anatomy and the notion of drives must seem crudely deterministic' (ibid.: 310). Yet, de Beauvoir's philosophy, Mitchell continues, envisions a human baby who 'comes free of predetermined characteristics into a world of pressures and 
problems against which it must act or around which it must navigate in a voluntary assertion of its liberty' (ibid.: 310). For the psychoanalyst here, this voluntary assertion of one's liberty sails too close to an 'implicit denial of the unconscious' (ibid.: 318 ).

Judith Butler, however, in her 1986 reading of de Beauvoir's text, steers us away from understanding the famous epithet -one is not born, but rather becomes, a woman- as an exclusively voluntaristic account of gender. Accepting that de Beauvoir relies on the "notion of choice in referring to the kind of volitional act through which gender is assumed', Butler is keen to qualify that to choose one's gender is not to say that one 'choose[s] it from a distance which signals an ontological juncture between the choosing agent and the chosen gender' (1986: 40).

Simone de Beauvoir's view of gender as an incessant project, a daily act of reconstitution and interpretation, draws upon Sartre's doctrine of prereflective choice and gives that difficult epistemological structure a concrete cultural meaning. Prereflective choice is a tacit and spontaneous act which Sartre terms "quasi knowledge." Not wholly conscious, but nevertheless accessible to consciousness, it is the kind of choice we make and only later realize we have made. Simone de Beauvoir seems to rely on this notion of choice in referring to the kind of volitional act through which gender is assumed. Taking on a gender is not possible at a moment's notice, but is a subtle and strategic project which only rarely becomes manifest to a reflective understanding. [...] The choice to assume a certain kind of body, to live or wear one's body a certain way, implies a world of already established corporeal styles. To choose a gender is to interpret received gender norms in a way that organizes them anew. (ibid.: 40) 
Several questions arise from this passage, not the least of which concerns the intersection of gender and choice. If for Butler, it is politically important that choice remains accessible to conscious agency; even if it can never be said to be wholly conscious - it is in de Beauvoir's language 'pre-reflective' - there is no suggestion that choice comes simply before the act: to act and to be acted upon are necessarily confused (ibid.: 39). As Butler writes just prior to the quoted passage, 'the temporal movement of this becoming [a gender] does not follow a linear progression' (ibid.). For Mitchell, such non-linearity would be a function of unconscious processes primed to interrupt chains of cause and effect, including movements from pre to post reflective states. Indeed, it is only by replacing de Beauvoir's language of the pre-reflective state with that of unconscious process that we might account for the kind of choice (nonnormative, non-linear) that both Butler and Mitchell might endorse: a choice that cannot be enacted 'at a moment's notice', nor settled 'once and for all'; in other words, a choice that is not completed before the act is committed, but which is rather multiple, and necessarily interruptive of other choices. Which is to say that the unconscious choice bound up with becoming a woman - or becoming a gender - necessarily entails a temporality that allows for contradictions.

\section{'Am I that name?'}

In her instructive text 'Am I that name?' Feminism and the Category of 'Women' in History, theorist and poet Denise Riley investigates the peculiar temporality of 'women'. Although hers isn't a work that foregrounds trans subjectivities, her hypothesis that "women" are only sometimes "women" resonates productively with our discussion of the becoming of gender, or, as Freud put it, woman's coming into being (1988: 96). '[W]omen' writes Riley, 'only sometimes live in the flesh distinctively of women, as it were, and this is a function of historical 
categorisations as well as of an individual daily phenomenology' (ibid.: 105). She explains that 'even the apparently simplest, most innocent ways in which one becomes temporarily a woman are not darting returns to a category in a natural and harmless state, but are something else: adoptions of, or precipitations into, a designation there in advance, a characterization of "woman"” (ibid.: 97). Thus, Riley asserts, 'it's not possible to live twenty-four hours a day soaked in the immediate awareness of one's sex. Gendered self-consciousness has, mercifully, a flickering nature' (ibid.: 96). Lest such a statement be charged with the complacency of cisprivilege, we can assume here a ready acceptance that for some more so than for others (and, critically in Riley's schema, for anyone at some times more so than at other times) the flickering nature of gendered self-consciousness threatens to become a full-on glare. The point can be made in tandem with Aidan, one of the subjects of Jana Marcus's photographic artwork 'Transfigurations: The Making of A Man' carefully read by Gayle Salamon in her 2010 text Assuming A Body: Transgender and the Rhetorics of Materiality. When Aidan reflects on his choice to have chest surgery after years of painful breast-binding he comments: 'Yesterday it was windy outside and my shirt pressed firmly against my chest and for the first time I wasn't conscious of my breasts...it felt amazing' (Salamon, 2010: 116). The idiomatic expression 'for the first time' is incredibly powerful because it narrates an affective moment of empowerment, and a relief from inhibition and pain. However, such a 'first time' does not signal a 'once and for all' - because, as Salamon points out, transition entails 'a continual becoming, rather than one act that begins and ends with a surgery' (ibid.). Furthermore, Aidan's narrative about how to become a gender by losing a crippling sense of self-consciousness speaks to one extraordinarily heroic attainment of the everyday (where the everyday means coping with the fact of having a human body). This necessitates periods of quietude from gendered selfconsciousness, minimally, sleep wherein we get both to rest, and to dream ourselves otherwise. I take this to be compatible with Riley's point about the flickering nature of sexed/gendered 
self-consciousness. It's important to underscore, then, that the motif of flickering is a temporal one: some kind of rhythm analysis is required to understand the on-and-off-ness, or the moreand-lessness of this sexed self-consciousness. To this end, I'd like to borrow from Riley what she offers as two exemplary moments, what we might call transitory scenes, in which women's consciousness of their place within the sex/gender system is liable to flash up, or to flicker on. Both scenes speak to the everyday situation of not knowing you're a woman, and then, suddenly, being made to know.

In the first, it's a matter of menstruation:

to be caught out by the start of menstruation, [...] the leakage of blood means that the sovereignty exercised by your hormonal cycle has gone and done it again.

In the second, it's a shout from the street:

You walk down a street wrapped in your own speculations; or you speed up, hell-bent on getting to the shops before they close: a car slows down, a shout comments on your expression, your movement; or there's a derisively hissed remark from the pavement. (??: 96-7)

At first glance, Riley's examples might look like repeating the old nature/nurture juxtaposition: The call of nature in the first example, and the call of man in the second. Attendant upon this, it might look like we have a recapitulation of the split between sex and gender. But this is not the case; rather in each instance, the subject is somehow called into an awareness of their being temporally (temporarily?) a woman. First, as an individual with a human body that 
menstruates: again, the point here is not to simply re-moor the category 'women' into biological or bodily determinisms; as Riley explains, 'you might view this badly timed event as being taken up -or thrown down- into your sex, but you need not do so'. The second scene is a familiar gendered hailing event, where the speech act from the other is the trigger for flicking the switch of gendered awareness from dim to bright. Again, however, the determination is ambiguous; to be interpellated as 'woman' will mean something different to all (and different things at different times to each) who answers to that name. The point to stress is that as interpellations, interruptions, or intrusions, both of these scenes exemplify the temporalization of being woman. Which is to say of all women, that they are only 'sometimes women'.

In her acclaimed Gender Outlaw text, transgender theorist, performer and activist Kate Bornstein demonstrates how the separatist designation 'women born women' is designed to keep transgender women out of certain spaces; she notes that '[a]side from the obvious absurdity of a newborn infant being called a woman, the phrase "woman born woman" just throws us back into the what's-a-woman question' (Bornstein, 2006: 242). Bornstein is named by Judith Butler as furthering the legacy of Simone de Beauvoir by demonstrating how 'becoming is the vehicle for gender itself' - her argument being that 'to go from $\mathrm{F}$ to $\mathrm{M}$, or from $\mathrm{M}$ to $\mathrm{F}$, is not necessarily to stay within the binary frame of gender, but to engage transformation itself as the meaning of gender' (Butler, 2004: 65). Accepting the kinship, we might, also, want to acknowledge the potential frictions between the two positions: Let's recall that in the terms of the social prison de Beauvoir challenges, she who answers to the name 'woman' exists between a man and a eunuch (woman is situated between a man and a man's opposite, though she herself is not man's opposite); de Beauvoir's political point of stress is an emancipatory one, which is to say that the intermediate, and therefore fundamentally ambiguous, position of woman, is to be overcome. Whereas in the Butler-Bornstein 
formulation, transformation is the vehicle for gender, for de Beauvoir woman (the creature described as feminine) is the mere vehicle for a movement between polarities that are not hers to take-up; she writes, '[w] $\mathrm{w}$ oman incarnates no stable concept; through her is made unceasingly the passage from hope to frustration, from hate to love, from good to evil, from evil to good. Under whatever aspect we may consider her, it is this ambivalence that strikes us first' (Beauvoir, 1997[1949]: 175). Evidently, for the author of The Second Sex, it is not to be celebrated that ' $[w]$ oman incarnates no stable concept'. Denise Riley contends differently; she remarks, 'that 'women' is indeterminate and impossible is no cause for lament' (??: 113-114). Indeed, with the notion of the 'sometimes woman' in mind, we might well affirm that the question of woman was never to be resolved through the stable incarnation of a concept, or the sustained identification with a single pole on the male-female binary. Contested ownership and usage-rights of 'woman'/'women' has become one of the most visible and virulent features of the contemporary gender debates. One point of focus concerns the use of additional markers to form sub-categories within the class 'women', i.e. ciswomen; transwomen. Whether taken as a sign of inclusion, or of further differentiation and division, these markers reassert the fantasylogic of I know you, now that I can name you. When, in recent years, 'cis' has been advanced to challenge a hierarchy by drawing attention to the unmarked norm, it has done so against a pervasive fantasy of the real woman; a designation, and political language act which has operated as an exclusionary apparatus across history. Indeed, the longer perspective reminds us how different feminist demands for political recognition have needed to mobilise 'woman' differently - sometimes asserting, sometimes questioning, and sometimes rejecting that name. ${ }^{12}$ This is because the question of woman as the indeterminate sex is much less a simple category, rather it is the place where categorization flounders. Which returns us finally to the question of the case. 


\section{Agnes interminable?}

In his reading of the case of Agnes, John Forrester catalogues several acknowledgments concerning the constitutive limitations of the case study: according to Winnicott, the case study is only illustrative - it can prove nothing; for the philosopher of science, Peter Caws, 'clinical findings cannot reliably be extrapolated beyond the case from which they are drawn'. Most interesting perhaps, is the famous comment from Clifford Geertz on thick description: "the essential task of theory building [...] is not to codify abstract regularities but to make thick description possible, not to generalize across cases, but to generalize within them' (??: 12829, emphasis mine). With an emphasis on the prepositions (beyond, across, within), we can ask, why it is, for Forrester, that a concern with the genre of the case study 'feeds directly into' the material of Stoller's case of Agnes (ibid.: 129, my emphasis). How might it be that, aside from any diagnostic value, a formal alliance pertains between the methodological question of the case study and the cultural question of gender as it's found expression from the 1960s on?

Training our eye to read for lines of movement within, the case study has a selfreferential quality that keeps in check the desire to move beyond the case in question. Rather than try to establish evidence to prove an abstract principle, or counter-pose an extant theorem, perhaps we can say, reworking de Beauvoir's grievance above, that a case 'incarnates no stable concept' - but, and this is key, that this is no cause for lament. If, as Adam Philips observes in his introduction to Forrester's work, 'we never quite know what any given case is an example of', this can only have something to do with the necessary 'failure' of psychoanalytic writing itself (reminding us how writing is symptomatic of an unconscious which is itself consubstantial with the knot of sexuality). Here, Forrester's choice of writer, Stoller, is entirely instructive. As a fervent critic of orthodox clinical prose, Stoller consistently calls for more 'humility' in the knowledge claims that analysts make. How, he enquires across his work, can the reader be "confident that the observations [that analysts] report are the foundations of the 
dynamics [they] describe'; and what is the reader to make of the vital role of the analyst in shaping their encounter with the named subject of the case (Stoller, 1985: 93)? Stoller writes:

In a science such as physics, one can describe what one observed without needing a subtle vocabulary and an articulate if not artful writing style. The report does not create or even shape the findings. But in reporting analytic observations, there can not be even a sentence that is not the writer's interpretation - that is, modification, editing, translating - of each observation. (ibid.: 178-9)

The suggestion being that though there are certain areas of study where choices of form (conscious, prereflective, or unconscious) matter little, there are other areas where the requirement to attend to the connection between how you represent what you think you know is wholly enfolded within the task: Stoller's 'gender identity', and the question of the case are two such examples. Moreover, the analyst himself is the vehicle through which the connection between form and content is expressed; he is his own 'rampantly fallible [research] instrument' (ibid.: 180). From his forceful presence in session transcripts, to the manifest pleasure he takes from turning a phrase, there's no denying Stoller's inimitable style as a writer-clinician; he vies for the reader's attention alongside the ostensible subject matter, prompting again the question, who or what is the subject of the case. This question, I'd suggest, preserves precisely the type of ambiguity necessary if writing and thinking in cases is, rather than merely observant, productive of new lines of movement from within. Concordant with the tribulations of sexed/gendered experience, to think in cases is to practice those lines of movement - the transitions, transferences, and interruptions - that characterize the non-linear temporalities of becoming. The very provisionality of a case articulates this: the case of Agnes which received 
renewed and seemingly definitive focus with the patient's late revelation, has been productively interrupted in many subsequent and contrapuntal readings, Forrester's included. Agnes interminable, perhaps? If so, this is because the 'calculated ambiguities' of writing, to cite from Adam Phillips's appraisal of Forrester's style, challenge us to tease apart Forrester's interest in Stoller's case of Agnes, from his interest in Forrester's case of Stoller - if these aren't quite the same, neither is their difference immediately obvious. With transferences alive and well, cases are necessarily multiple.

Alongside Geertz, Stoller affirms for us that it's interpretations all the way down. And yet though Stoller knew that 'there is no such thing as a clear sentence', he had no desire to eradicate from his thinking and writing style a 'yearning for clarity' because 'clarity asks; it does not answer' (1985: x). It has been my suggestion across this piece that to think in cases may be, however intermittently, to uncover from within the statement - I know you, now that I can name you, the question - am I that name?

\section{References}

Appignanesi, L. and Forrester, J. (2005[1992]) Freud's Women. London, Phoenix.

Beauvoir, S. de. (1997[1949]) The Second Sex, trans. and ed. H.M. Parshley. London: Vintage Books.

Bornstein, K. (2006) 'Gender Terror, Gender Rage', in S. Stryker and S. Whittle (eds) The Transgender Studies Reader. New York: Routledge, pp. 236-43.

Butler, J. (1986) 'Sex and Gender in Simone de Beauvoir's Second Sex', Yale French Studies 72: $35-49$.

Butler, J. (2004) Undoing Gender. Oxford: Routledge.

Butler, J. (2006[1990]) Gender Trouble: Feminism and the Subversion of Identity. New York \& London: Routledge Classics. 
Copjec, J. (1994) ‘Sex and the Euthanasia of Reason’, in J. Copjec (ed.) Supposing the Subject. London: Verso, pp. 16-44.

Denzin, N. K (1990) 'Harold and Agnes: A Feminist Narrative Undoing', Sociological Theory 8(2): 198-216.

Garfinkel, H. (1984[1967]) Studies in Ethnomethodology. Cambridge: Polity Press.

Geertz, C. (1973) 'Thick Description: Towards an Interpretative Theory of Culture', in The Interpretation of Cultures: Selected Essays. New York: Basic Books, pp. 3-30.

ffytche, M. (this Issue) 'Throwing the Case Open: The Impossible Subject of Luisa Passerini's Autobiography of a Generation'.

Forrester, J. (1996) 'If $p$, Then What? Thinking in Cases', History of the Human Sciences 9(3): $1-25$.

Forrester, J. (2017) Thinking in Cases. Cambridge: Polity Press.

Freud, S. (1899) Letter from Freud to Fliess, August 1, 1899. The Complete Letters of Sigmund Freud to Wilhelm Fliess, 1887-1904, ed. J. M. Masson, 1985, the Belknap Press of Harvard University Press, pp. 363-4.

Freud, S. (1933) 'Femininity', New Introductory Lectures On Psycho-Analysis. The Standard Edition of the Complete Psychological Works of Sigmund Freud, Volume XXII (19321936): 112-35.

Heath, S. (1986) 'Joan Riviere and the Masquerade', in V. Burgin, J. Donald and C. Kaplan (eds) Formations of Fantasy. London: Routledge, pp. 45-61.

Hughes, J. M. (1999) Freudian Analysts / Feminist Issues. New Haven: Yale University Press. Lacan, J. (1998[1978]) The Four Fundamental Concepts of Psychoanalysis: The Seminar of Jacques Lacan, Book XI, ed. J.-A. Miller, trans. A. Sheridan. New York \& London: W.W. Norton Company. 
Mitchell, J. (2000[1974]) Psychoanalysis and Feminism: A Radical Reassessment of Freudian Psychoanalysis. London: Penguin Books.

Nelson, M. (2016) The Argonauts. London: Melville House UK.

Newsnight, (2016) [TV] British Broadcasting Corporation, aired 05.01.16 at 22:30.

Riley, D. (1988) 'Am I that name?' Feminism and the Category of 'Women' in History. Basingstoke: Palgrave Macmillan.

Riviere, J. (1929) 'Womanliness as a Masquerade', The International Journal of Psychoanalysis 10: 303-13.

Rose, J. (1982) 'Introduction', in J. Mitchell and J. Rose (eds) Feminine Sexuality: Jacques Lacan and the Ecole Freudienne. New York: Pantheon, pp. 27-58.

Salamon, G. (2010) Assuming A Body: Transgender and Rhetorics of Materiality. New York: Columbia University Press.

Schilt, K. (2016) 'The Importance of Being Agnes', Symbolic Interaction 39(2): 287-94.

Sedgwick, E. K. (1990) Epistemology of the Closet. Berkeley, Los Angeles: University of California Press.

Stoller, R. J. (1984[1968]) Sex and Gender: The Development of Masculinity and Femininity. London: Karnac Books.

Stoller, R. J. (1985) Observing the Erotic Imagination. New Haven \& London: Yale University Press.

Stoller, R. J., Garfinkel, H. and Rosen, A. C. (1960) 'Passing and the Maintenance of Sexual Identification in an Intersexed Patient', Archives of General Psychiatry (2): 279-84.

Willemsen, J., Della Rosa, E. and Kegerreis, S. (2017) 'Clinical Case Studies in Psychoanalytic and Psychodynamic Treatment', Frontiers in Psychology 8: 108. 
Winnicott, D. W. (1975[1952]) 'Anxiety Associated with Insecurity', in Through Paediatrics to Psycho-Analysis. London: The Hogarth Press and the Institute of Psycho-Analysis, pp. $97-100$.

\section{Notes}

1. In hearing about Agnes's mother, as well as Agnes's mother's mother, Stoller learns that the former had played a night-time game with her son between the ages of 2 and 8 called "mother hen and baby chick" creating an "extrauterine "womb" with their bodies for both to fall asleep in (??: 137). The early intimacy and 'over-love' between Agnes's mother and her child speaks to Stoller's account of the role of bodily contact in 'excessive mother-infant symbiosis', and evidences his working theory that transsexual boys are feminized by 'too much contact with the mother's body for too long and a father who is psychologically absent' (ibid.: 139, 307, 138). On a critical note, whether the familiar 'too-much-mother, not-enough-father' story is a theory as such, or more of a (psychoanalytic) axiom remains a moot point.

2. A further reason Agnes's case is so pertinent to Forrester's Thinking in Cases project is because it traverses all the domains in which case-work applies - 'medicine, law, philosophy $[\ldots]$ and the therapies of the world' (Forrester, 1996: 21).

3. 'Subversive confusion' is one of the tactics named by Judith Butler in Gender Trouble. The project being to produce gender trouble 'not through the strategies that figure a utopian beyond, but through the mobilization, subversive confusion, and proliferation of precisely those constitutive categories that seek to keep gender in its place by posturing as the foundational illusions of identity' (2006[1990]: 46). 
4. Maggie Nelson refers to her identity phobia in the following passage where she recounts meeting Eve Kosofsky Sedgwick for the first time in a graduate seminar on 'Non-Oedipal Models of Psychology':

By way of introduction, she announced that she had started going to therapy because she wanted to be happier. To hear a scary theoretical heavyweight admit such a thing changed my life. Then, without missing a beat, she said she wanted to play a quick get-to-know-you game involving totem animals. [...] Totem animals? [...] The game placed an icy finger on my identity phobia: it was but a short leap from here, I felt, to the index card, Sharpie, and lapel pin. (2016: 139)

5. That this ambiguity may be a key feature of case-study writing is explored elsewhere in this volume. For example, in his discussion of Luisa Passerini's Autobiography of a Generation, Matt ffytche considers how the 'collapse' of the 'methodological boundary between the investigator and the investigated' constitutes one of the crisis points that prevents a straightforward genre classification of Passerini's work (page numbers).

6. See Willemsen et al. (2017) for a recent discussion of the some of the debates regarding the methodological value of the clinical case study for psychoanalysis.

7. 'Agnes' again offers a fine instance of this. For example, in Garfinkel's presentation there are several points where the narrative becomes polyvocal, with Garfinkel, Stoller and Agnes all competing for space on the page. See Denzin (1990) for discussion of the textual interplay (and powerplay) of Garfinkel's Agnes.

8. The inquiry's report informed the 2018 government consultation on the reform of the Gender Recognition Act of 2004, the analysis of which, at the time of writing, is still to be announced. 
9. Though the third term in the sequence is not stated in the dialogue, it nonetheless presents itself as an obvious run-on in this chain of signifiers, and refers back to the received wisdom that Forrester, through Robert Stoller and Harry Benjamin, historicises in his chapter on inventing gender identity.

10. Famously, D.W. Winnicott declared that 'there's no such thing as a baby' underscoring the constitutive role of the environment/mother through which the baby finds herself, and comes to be known by others (Winnicott, 1975[1952]: 99).

11. Although set some 200-plus pages apart, this chapter, which is entitled 'Childhood', reads as an accompaniment chapter to Book One's 'The Psychoanalytic Point of View', wherein woman's position between male and eunuch takes on fuller significance with respect to the psychoanalytic theories of the castration complex and penis envy.

12. Take Sojourner Truth's 'Ain't I a Woman?' speech of 1851 to the Women's Convention in Akron, Ohio, and Monique Wittig's closing statement that 'lesbians are not women' in her 1978 'Straight Mind' lecture at the Modern Language Association Convention in New York as two canonical examples in the history of feminist address that attest to ways in which the identification 'woman/women' is transitive.

\section{Author biography}

Julie Walsh....... 